\title{
Localized Proteasomal Degradation: From the Nucleus to Cell Periphery
}

\author{
Xing Guo ${ }^{1,2} \mathbb{B}$
}

1 Life Sciences Institute, Zhejiang University, Hangzhou 310058, China; xguo@zju.edu.cn

2 Zhejiang Provincial Key Laboratory for Cancer Molecular Cell Biology, Hangzhou 310058, China

Citation: Guo, X. Localized Proteasomal Degradation: From the Nucleus to Cell Periphery. Biomolecules 2022, 12, 229. https:// doi.org/10.3390/biom12020229

Academic Editors: Robert J. Tomko and Soyeon Park

Received: 13 January 2022

Accepted: 27 January 2022

Published: 29 January 2022

Publisher's Note: MDPI stays neutral with regard to jurisdictional claims in published maps and institutional affiliations.

Copyright: (C) 2022 by the author. Licensee MDPI, Basel, Switzerland. This article is an open access article distributed under the terms and conditions of the Creative Commons Attribution (CC BY) license (https:/ / creativecommons.org/licenses/by/ $4.0 /)$.

\begin{abstract}
The proteasome is responsible for selective degradation of most cellular proteins. Abundantly present in the cell, proteasomes not only diffuse in the cytoplasm and the nucleus but also associate with the chromatin, cytoskeleton, various membranes and membraneless organelles/condensates. How and why the proteasome gets to these specific subcellular compartments remains poorly understood, although increasing evidence supports the hypothesis that intracellular localization may have profound impacts on the activity, substrate accessibility and stability/integrity of the proteasome. In this short review, I summarize recent advances on the functions, regulations and targeting mechanisms of proteasomes, especially those localized to the nuclear condensates and membrane structures of the cell, and I discuss the biological significance thereof in mediating compartmentalized protein degradation.
\end{abstract}

Keywords: proteasome; membrane; nucleus; condensate; ubiquitination; myristoylation

\section{Introduction}

The 26S proteasome is situated at the core of the ubiquitin-proteasome system (UPS), responsible for selective degradation of the majority of cellular proteins in eukaryotes. For over three decades since its discovery, the proteasome has been thoroughly studied with regard to its composition, structure, activity, regulation and relation to health and disease. The fully assembled $26 \mathrm{~S}$ proteasome holoenzyme consists of a 20S core particle (CP, formed by homologous $\alpha$ and $\beta$ type subunits) and one or two $19 S$ regulatory particles (RP, formed by six ATPase subunits called Rpt1-6, and thirteen non-ATPase subunits known as Rpns) [1-10]. Recent structural studies have significantly furthered our knowledge about how the proteasome recognizes and processes ubiquitinated substrates $[6,11,12]$. The success of proteasome inhibitors (e.g., Bortezomib/Velcade ${ }^{\circledR}$ ) in treating multiple myeloma [13] has spurred intensive research on developing proteasome-targeting compounds for therapeutic uses toward cancer and autoimmune diseases, whereas (re-)activating the proteasome by small molecules has also emerged as an attractive strategy for alleviating symptoms associated with neurodegeneration and aging [14-19]. A better understanding of the function and regulation of the proteasome is of great biological and clinical importance.

As a soluble and highly abundant macromolecular complex [20-22], the proteasome resides in both the nucleus and cytoplasm of a cell and has been found associated with various subcellular structures, including the chromatin, cytoskeleton, nuclear envelope, plasma membrane, the cytosolic side of membrane-bound organelles and membraneless organelles/condensates (see below). Despite their pervasive presence, proteasomes are not evenly distributed in all cells. On a global scale, asymmetric cell division can lead to unequal inheritance of proteasomes between the daughter cells [23-26]. The specific subcellular localizations of proteasomes are often cell type- and growth status-dependent and dynamically regulated under both basal and stimulated/stress conditions [27-29]. A classic example is that in yeast, proteasomes are predominantly present in the nucleus of proliferating cells; but upon quiescence or carbon starvation, nuclear proteasomes are 
rapidly exported to the cytosol, where they are concentrated in a membraneless structure called proteasome storage granule (PSG) [30]. PSGs quickly resolve when yeast cells resume growth in nutrient-rich media and proteasomes re-gather in the nucleus. This reversible process is believed to protect the proteasome repertoire from autophagic degradation under stress conditions, while allowing them to regain function as soon as the stress is relieved [30,31].

Proteasomes also exist extracellularly. Original studies have shown that secreted proteasomes from ascidian sperms can digest vitelline coat proteins outside the egg and are required for egg penetration and fertilization [32-34]. Circulating proteasomes (cproteasomes) were also found in humans around the same time [35], which has been confirmed by a series of subsequent studies (see reviews [36-38] and references therein). Present in the blood as well as other bodily fluids, these c-proteasomes are mostly in the form of 20S, probably due to the low-ATP extracellular environment that does not support RP-CP association [39,40]. Nonetheless, they are enzymatically active, and elevation of their levels is often correlated with either malignancy or tissue injury/damage, making them a promising biomarker for disease diagnosis [36-38]. How the proteasomes exit the cell remains a matter of debate, although a likely mechanism is via exosome-mediated nonconventional secretion $[36,41]$. The pathophysiological roles and regulatory mechanisms of extracellular proteasomes have yet to be fully understood.

Various mechanisms have been identified to target protein substrates to different subcellular regions for proteasomal degradation [42-50]. On the flip side, proteasomes should be available at the site of degradation or can be mobilized to meet the substrates. In addition to the examples introduced above, the dynamic localizations of the proteasome have been extensively studied (particularly in yeast) and summarized in a series of reviews [51-55]. Here, I will focus on the latest findings about nuclear-localized and membrane-associated proteasomes in mammalian cells and discuss the targeting mechanisms, biological functions, as well as regulations of proteasomes at these specific compartments.

\section{Proteasomes in the Nucleus}

A considerable amount of proteasomes exist in the nucleus, where they play pivotal roles in regulating mitotic cell cycle [56,57], meiosis [58-60], transcription/chromatin remodeling/epigenetic control [61-64], RNA splicing [65,66], DNA damage repair [67-69] and nuclear protein quality control $[42,49,70]$, among others. There are also nuclear-specific proteasome activators (e.g., PSME3/REG $\gamma$ and Blm10) and regulators that control these processes [71-75].

\subsection{Nuclear Targeting of the Proteasome}

In yeast, nuclear proteasomes are essential for cell survival [76]. Unlike in higher organisms, the nuclear envelope (NE) of a yeast cell remains intact during closed mitosis, and active nuclear import of the proteasome across the NE is necessary for continuous cell proliferation. Early studies identified putative nuclear localization signals (NLS) in certain $\alpha$ subunits of yeast and archaeal proteasomes, some of which were later found to be functionally conserved in their mammalian homologs [77-81]. Direct recognition of NLS by the importin complex is therefore important for trafficking proteasome subunits and sub-assemblies into the nucleus [51].

NLS has also been identified in the 195 subunits, Rpn2 and Rpt2. Although both of these NLS sequences are functional in binding importins and guiding non-nuclear proteins to the nucleus in yeast, only the Rpn2-NLS was shown to be primarily responsible for nuclear import of the $19 \mathrm{~S}$ base complex (including Rpt1-6, Rpn1, 2, 10 and 13). The putative NLS of Rpt2 only provided secondary functions when the Rpn2-NLS was inactivated [82]. In mammals, these NLS sequences are only partly conserved in Rpn2 and Rpt2, and their relevance to nuclear localization of the proteasome has not been examined. Of note, positively charged residues at the C-terminal half of the bipartite ScRpt2-NLS (KFGRKKRK) are also present in human Rpt2 ( $\left.{ }_{32} \mathrm{RVGKKKKK}_{39}\right)$, a region sandwiched between Rpt2 and 
its neighboring subunit Rpn1, possibly inaccessible to the importins [12]. On the other hand, the N-terminal part of ScRpt2-NLS roughly corresponds to ${ }_{15} \mathrm{KKDDKDKKKK}_{24}$ of human Rpt2, which was recently suggested to form a charge-charge interaction with phosphorylated Ser361 of Rpn1. This interaction is required for proper proteasome assembly in human cells, and mutation of these lysine residues weakened Rpt2 incorporation into the proteasome [83]. It should be pointed out that Rpn1-Ser361 phosphorylation does not occur in yeast, given the lack of phosphosite, therefore the ScRpt2-NLS may be more available for importin binding. In addition, aa. 1-24 of human Rpt2 is sufficient for bringing GFP to the cell membrane [84] largely due to N-myristoylation of this sequence (see below), while the myristoylation site was omitted in the GFP targeting study with yeast Rpt2-NLS [82]. These observations suggest that similar NLS-like motifs of the same proteasome subunit may have different functions in mammalian cells and yeast, which may be determined by the subtle sequence differences, assembly status and modifications of the subunit itself and its adjacent subunits.

The proteasome may be imported into the nucleus as free subunits and assembly intermediates as noted above, and it can also pass through the nuclear pore complex (NPC) as assembled $20 \mathrm{~S}$ or $26 \mathrm{~S}$ particles $[21,85]$. This is possible owing to the elasticity of the NPC structure $[86,87]$ and depends on the importins. In addition to direct importin binding to the NLS sequences, which may be masked in the proteasome complex $[51,77,80]$, nuclear translocation of the $20 \mathrm{~S}$ and $26 \mathrm{~S}$ proteasomes can be facilitated by NLS-containing adaptor proteins that simultaneously interact with the proteasome and importins. Sts1 in budding yeast [88-90] and its ortholog, Cut8, in fission yeast [91,92] both possess NLS, form dimers, bind the proteasome and are required for proper localization of proteasomes in the nucleus. A homolog of Sts1/Cut8 has been found in fruit fly. Importantly, both Sts1 and Cut 8 are substrates of the proteasome with a very short half-life, and their ubiquitindependent (Cut8) and -independent (Sts1) degradation is coupled with their ability to mediate proteasome transport into the nucleus. Thus, these proteins serve as regulators, sensors and targets of nuclear proteasomes.

Very recently, a functional counterpart of Sts1/Cut8 was identified in human cells through a CRISPR screen for regulators of c-myc. Among the top hits was the transcription co-activator AKIRIN2, whose depletion significantly stabilized the c-myc protein, as well as many known nuclear targets of the proteasome [93]. AKIRIN2 is highly conserved through evolution, especially in vertebrates. Showing no obvious sequence identity with Sts1/Cut8, AKIRIN2 functions similarly to these yeast proteins in controlling proteasome nuclear localization. First, AKIRIN2 harbors an N-terminal bipartite NLS recognized by a particular importin, IPO9, which is also important for nuclear import of proteasomes in Drosophila germ cells [94]. Second, AKIRIN2 can homodimerize via its coiled-coil domain and preferentially binds assembled 20S and 26S proteasomes through its highly conserved C-terminal SYVS motif. The cryo-EM structure of the AKIRIN-20S CP complex has revealed that the SYVS tails insert into specific pockets formed between adjacent $\alpha$ subunits that are known to be occupied by the C-termini of Rpt subunits upon RP-CP association. The coiled-coils further lie across the surface of the $\alpha$ ring. This mode of interaction suggests that AKIRIN2 dimers can bind and promote nuclear import of free $20 \mathrm{~S}$ $\mathrm{CP}$ and singly capped $26 \mathrm{~S}$ proteasome (RP-CP) but not the doubly capped $30 \mathrm{~S}$ proteasome (RP-CP-RP) [93,95]. Third, same as Sts1 and Cut8, AKIRIN2 is also an unstable protein that can be rapidly degraded by the proteasome. Finally, AKIRIN2 is fundamentally important for nuclear proteasomal degradation and required for cell survival. In particular, following (open) mitosis, AKIRIN2 controls the re-accumulation of nuclear proteasomes after the NE reforms. This fits well with its transcriptional upregulation prior to mitotic onset $[93,96]$. Together, AKIRIN2 and Sts1/Cut8 constitute a highly conserved strategy used by the cell to ensure a proper abundance of proteasomes in the nucleus. 


\subsection{Nuclear Condensates of the Proteasome}

The proteasome is an integral component of the protein quality control system (PQC) [97], which often functions in spatially organized compartments within a cell [48]. Proteasome association with distinct subcellular structures becomes more evident under stress conditions, as typified by the formation of juxtanuclear quality control compartment (JUNQ), insoluble protein deposit (IPOD)/aggresome, intranuclear quality control compartment (INQ), stress granule (SG) and other cellular bodies/aggregates. Much of this knowledge was gained from studies in yeast, while recent findings in higher organisms have highlighted the evolutionary conservation and significance of proteasome compartmentalization in response to proteostasis stress [44-48,50,98-105].

Several groups have recently reported proteasome-containing condensates forming in the nucleus of mammalian cells [106-109]. Although detected in different cell types with different stimuli, these subnuclear structures share several common features: (1) They quickly appear under stress and then resolve either spontaneously or after the cells are returned to normal conditions; (2) These proteasome foci are distinct from known nuclear structures, such as PML bodies, Cajal bodies, DNA damage foci, nuclear speckles and nucleoli; (3) They are fluid membraneless organelles formed by liquid-liquid phase separation (LLPS) [110]; (4) All of them contain proteins modified by K48-linked ubiquitin chains, which serve as a critical nucleating factor to recruit proteasomes. Specifically, the ubiquitin shuttle protein Rad23B can establish multivalent binding with ubiquitin chains via its tandem ubiquitin-associated (UBA) domains, providing a driving force for LLPS. Rad23B also docks onto the proteasome via its ubiquitin-like (UBL) domain, thus attracting proteasomes to the ubiquitinated proteins [106,109]. Similarly, p62/SQSTM1, a key regulator of macroautophagy, also contains a UBA domain for ubiquitin binding and uses its PB1 domain for proteasome interaction. Nuclear retention of p62 was shown to be sufficient to induce proteasome phase separation [108]; (5) Proteasomes in these nuclear condensates are fully assembled, active $26 \mathrm{~S}$ complexes, and their proteolytic activity can be enhanced by the high local concentrations of both the proteasome and the substrates. Therefore, in contrast to the cytosolic PSG observed in yeast, which contains dissociated RPs and CPs, stress-induced nuclear proteasome foci in mammalian cells are active degradation centers of ubiquitinated proteins.

There were also unique findings reported about each type of these nuclear proteasome condensates. By treating cells with sucrose, glucose or $\mathrm{NaCl}$, Yasuda et al. first described hyperosmotic stress-induced proteasome phase separation in the nucleus [106]. This process not only relied on ubiquitination (as determined by E1 inhibition) and Rad23B but also on UBE3A, a proteasome-associated E3 ubiquitin ligase that was also present in the condensates. Song et al. later found that, in addition to K48-linked ubiquitin chains, proteins in the same kind of liquid droplets were also modified by K11/K48-branched chains [111]. UCH37, a long-recognized proteasome-associated deubiquitinase (DUB), was also present at the sucrose-induced proteasome foci. With a unique de-branching activity toward $\mathrm{K} 11 / \mathrm{K} 48$ and $\mathrm{K} 6 / \mathrm{K} 48$ ubiquitin chains [111,112], UCH37, together with the ATPase p97/VCP, played an important role in disentangling the ubiquitinated proteins and resolving the condensates through proteasomal degradation [106,111]. Hyperosmolarity led to nucleolar stress and impaired ribosome biogenesis. Unassembled orphan ribosomal proteins were targeted to the proteasome condensates where they were degraded, thereby preventing their aggregation in the nucleus under stress. As such, the nuclear proteasome droplets serve as an important quality control mechanism to protect the cell from hyperosmotic stress.

Nuclear puncta of proteasomes under hypertonic treatment were also observed by Lee et al. [107]. Using a higher $\mathrm{NaCl}$ concentration and prolonged treatment, these investigators noted that proteasome foci decorated the nuclear membrane, probably representing a late-stage response to more severe hyperosmotic stress. The formation of these intranuclear foci was not regulated by the kinase p38, which has been shown to phosphorylate Rpn2 in response to hyperosmotic stimulation [113]. However, pharmacologic inhibition of either 
importin or exportin abrogated nuclear proteasome condensation under the same stress condition, suggesting the requirement for nucleocytoplasmic shuttling of the proteasome and/or other factors. Moreover, NPC components were detected in cytosolic stress granules after hyperosmotic shock, indicative of disruption of the nuclear pore. It remains to be determined how this happens and whether it underlies the unique localization of proteasome foci at the nuclear envelope.

To understand the nuclear function of p62, Fu et al. knocked out p62 from cells and replaced with a nuclear-trapped version, p62 $\triangle$ NES [108]. Under basal conditions, p62 $\triangle$ NES spontaneously underwent LLPS, and the resulting nuclear droplets contained not only ubiquitinated proteins (K48- and K63-linked) but also E1, E2, E3 enzymes, active $26 S$ proteasomes and DUBs, representing all components of the UPS. Indeed, p62 $\triangle N E S$ promoted proteasomal degradation of several nuclear substrates, including NLS-GFP-CL1, free proteasome subunits and the transcription factors c-myc and c-jun. Interestingly, these proteasome-containing p62 condensates could fuse with sucrose-induced proteasome condensates [106]. Compared to p62-null cells, p62 $\mathrm{N}$ NES-reconstituted cells showed better survival after oxidative stress and heat shock, pointing to a cytoprotective role of p62 via regulating nuclear PQC [108].

Another form of stress is nutrient deprivation. In yeast, carbon (glucose) starvation leads to PSG formation, while nitrogen starvation promotes proteasome degradation by autophagy ("proteaphagy") [30,31,114,115]. On the contrary, Uriarte et al. found that nitrogen (amino acid) starvation of mammalian cells induced nuclear proteasome condensates that they named SIPAN (Starvation-Induced Proteasome Assemblies in the Nucleus) [109]. Again, this structure contained active 26S proteasomes, K48-linked ubiquitin chains, Rad23B, as well as PSME3/REG $\gamma$. Ubiquitination and Rad23B, but not PSME3, were required for SIPAN formation, whereas detergent and hypotonic treatments quickened its dissipation. Interestingly, non-essential amino acids (NEAA), but not essential amino acids (EAA), could effectively block SIPAN formation and promote its resolution. SIPAN resolution also depended on the DUB activity of UCH37/UCHL5 and USP14 but was independent of E1, p97/VCP or proteasome activity when nutrients were available. Unlike the observations made by Yasuda et al. with hyperosmotic stress [106], amino acid deprivation did not cause nucleolar stress. Instead, prolonged amino acid starvation triggered p53-mediated apoptosis, while depletion of Rad23B (which eliminated SIPAN) or PSME3 inhibited upregulation of p53 and its target genes, maintaining cell survival under starvation. Although a clear link between these pro-apoptotic factors and SIPAN has yet to be established, the investigators noticed an inverse correlation between SIPAN formation and cell survival upon starvation. Compared to non-cancerous cells, cancer cells and oncogene-transformed "normal" cells showed a much reduced propensity to form SIPAN when deprived of amino acids. In this sense, SIPAN differs from all the other nuclear proteasome condensates discussed above and appears to have a deleterious effect on cells, which was suggested to be a potential defense mechanism against cancer [109].

In all, various stress conditions have been shown to trigger condensation of nuclear proteasomes via LLPS. These structures can be viewed as distinct entities based on the signals that regulate their formation/dissipation, their biochemical compositions and biological functions, but they may also be related both biochemically and functionally. Table 1 summarizes the commonalities and distinctions between these proteasome condensates. 
Table 1. Characteristics of nuclear proteasome condensates under various stress conditions.

\begin{tabular}{|c|c|c|c|c|}
\hline Reference & Yasuda et al. [106] & Lee et al. [107] & Fu et al. [108] & Uriarte et al. [109] \\
\hline Condensate induced by & Hyperosmotic stress & Hyperosmotic stress & $\begin{array}{l}\text { Nuclear retention of } \\
\text { p62, oxidative and } \\
\text { heat stress }\end{array}$ & $\begin{array}{l}\text { Nutrient starvation } \\
\text { (NEAA depletion) }\end{array}$ \\
\hline Formation depends on & $\begin{array}{l}\text { Ubiquitination, Rad23B, } \\
\text { UBE3A }\end{array}$ & $\begin{array}{l}\text { Ubiquitination, } \\
\text { nucleocytoplasmic } \\
\text { trafficking }\end{array}$ & $\begin{array}{l}\text { Ubiquitination, protein } \\
\text { synthesis, p62 }\end{array}$ & Ubiquitination, Rad23B \\
\hline Clearance depends on & $\begin{array}{c}\text { Proteasome activity, } \\
\text { p97/VCP, } \\
\text { UCH37/UCHL5 }\end{array}$ & Proteasome activity & Proteasome activity & $\begin{array}{l}\text { UCH37/UCHL5, } \\
\text { USP14 }\end{array}$ \\
\hline Driven by & LLPS & LLPS & LLPS & LLPS \\
\hline Form of proteasome & $\begin{array}{c}\text { Active, } 26 S \\
\text { holoenzyme }\end{array}$ & $\begin{array}{c}\text { Active, } 26 \mathrm{~S} \\
\text { holoenzyme }\end{array}$ & $\begin{array}{c}\text { Active, } 26 \mathrm{~S} \\
\text { holoenzyme }\end{array}$ & $\begin{array}{c}\text { Active, } 26 \mathrm{~S} \\
\text { holoenzyme }\end{array}$ \\
\hline $\begin{array}{l}\text { Substrates of } \\
\text { proteasome }\end{array}$ & $\begin{array}{l}\text { Orphan ribosome } \\
\text { proteins (RPs) }\end{array}$ & & $\begin{array}{c}\text { NLS-GFP-CL1, } \\
\text { unassembled } \\
\text { proteasome subunits, } \\
\text { c-myc, c-jun }\end{array}$ & \\
\hline $\begin{array}{l}\text { Other UPS-related } \\
\text { components }\end{array}$ & $\begin{array}{c}\text { Ub chains (K48-linked } \\
\text { but not K63-linked, } \\
\text { K11/K48), } \\
\text { UCH37 [111] }\end{array}$ & Ub chains (K48-linked) & $\begin{array}{c}\text { Ub chains (K48-linked } \\
\text { and K63-linked) } \\
\text { E1/E2/E3s, DUBs, } \\
\text { chaperones }\end{array}$ & Ub chains (K48-linked) \\
\hline $\begin{array}{l}\text { Accompanied } \\
\text { phenotypes }\end{array}$ & Nucleolar stress & $\begin{array}{c}\text { Condensates near NE, } \\
\text { Nups found in stress } \\
\text { granule }\end{array}$ & $\begin{array}{l}\text { p62 condensates can } \\
\text { fuse with those } \\
\text { induced by } \\
\text { sucrose [106] }\end{array}$ & $\begin{array}{l}\text { No nucleolar stress. } \\
\text { Cells protected by } \\
\text { NEAA but not EAA }\end{array}$ \\
\hline Biological function & $\begin{array}{c}\text { Prevent RP aggregation, } \\
\text { protect cells from } \\
\text { hyperosmotic stress }\end{array}$ & $\begin{array}{l}\text { Protect cells from } \\
\text { hyperosmotic stress }\end{array}$ & $\begin{array}{l}\text { Nuclear PQC. Protect } \\
\text { cells from heat stress }\end{array}$ & $\begin{array}{l}\text { A possible defense } \\
\text { mechanism against } \\
\text { oncogenic } \\
\text { transformation }\end{array}$ \\
\hline
\end{tabular}

\section{Proteasomes at the Membranes}

Membrane localization of the proteasome has been documented since the early 1990 's [116,117]. Numerous subsequent studies have documented proteasomes in close contact with nuclear envelope-ER [92,118-124], the Golgi apparatus [125,126], endosomes [127,128], plasma membrane $[129,130]$, mitochondria [123,131-136] and so on. Proteasomes at the membranes are particularly important for organelle quality control processes, such as ERassociated degradation (ERAD), endosome and Golgi-associated degradation (EGAD) and mitophagy [120,125,126,137-141]. In addition, proteasomes located at neuronal synapses are also critical for neurotransmission and synaptic plasticity [142-146]. In these cases, the proteasome associates peripherally with the membrane by binding to membrane-resident proteins. This can occur directly between proteasome subunits and membrane proteins. Alternatively, proteasomes can be indirectly recruited to the membrane through binding to the ubiquitin moiety of modified membrane proteins, proteasome-interacting proteins (sometimes in concert with motor proteins and cytoskeleton) $[147,148]$ or even RNAs that function as protein scaffolds [149]. Together, these represent the most common mode of proteasome-membrane interaction, while the proteasome can also locate to the membrane in two other ways, as elaborated below (Figure 1).

\subsection{Neuronal Membrane Proteasomes}

Ramachandran et al. reported a surprising type of membrane-associated proteasomes designated as the neuronal membrane proteasomes (NMPs) [150,151]. As the name suggests, these proteasomes are found at pre- and post-synaptic plasma membranes in neurons, 
which were confirmed by immunogold electron microscopy (IEM), surface biotinylation, immunofluorescence imaging with antibody feeding and proteinase protection assays. NMPs are thought to be comprised of the 20S CP only, since no 19S components (such as Rpt5 or Rpn1) were found by IEM in these particular membrane proteasomes. NMPs are capable of degrading newly synthesized polypeptides, which are still unfolded, to short peptides. More fascinatingly, the authors showed that these peptide products could exit the cells through NMPs and be released into the synaptic cleft to function as neurotransmitters. Therefore, NMPs function not only as a protein degrader but also a new form of membrane channel to mediate cell-cell communications [152]. Although these findings were very unique and intriguing, the molecular and biochemical details of the NMPs remain unclear. First, it is curious that the 20S CP, which is soluble and hydrophilic, could be fully embedded within the hydrophobic membrane. How is the CP targeted to the plasma membrane and how does it overcome the energy barrier to traverse the lipid bilayer? It was proposed that glycoproteins, such as GPM6, could facilitate this process [151], but a clear mechanistic explanation is still needed. Second, does the NMP exhibit any substrate selectivity? The proposed role of NMPs in cleaving nascent proteins suggests that substrate availability depends on localized protein synthesis by ribosomes in the vicinity [150]. However, if the NMP complex also contained auxiliary factors yet to be identified, it might recognize and process folded protein substrates as well. On the other hand, the recent discovery that the 20S CP can by itself degrade ubiquitinated proteins [153] also implies that NMPs may have a broader range of substrates. A following question is the molecular composition and regulatory mechanisms of the NMPs. Finally, what is the function of NMP in vivo? Additionally, how can we specifically maneuver it for research and therapeutic purposes without affecting the bulk of proteasomes inside the cell? Answering these questions will depend on new technical advances in imaging, chemical biology, proteomics, structural biology and genetic models, which makes it challenging but also rewarding at the same time.

A

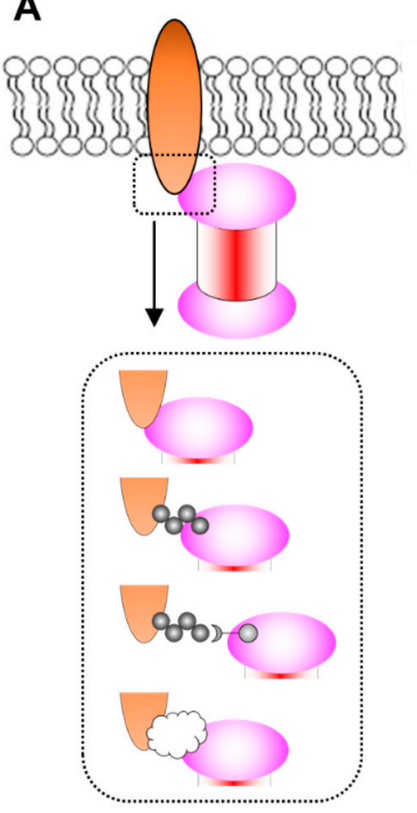

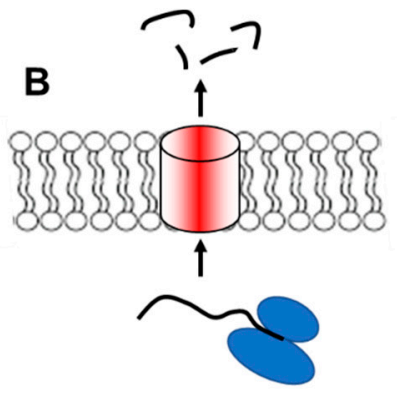

C

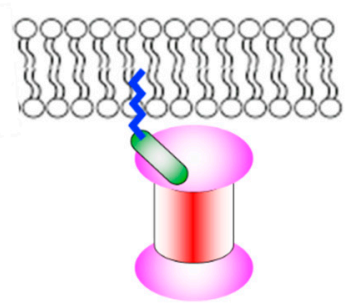

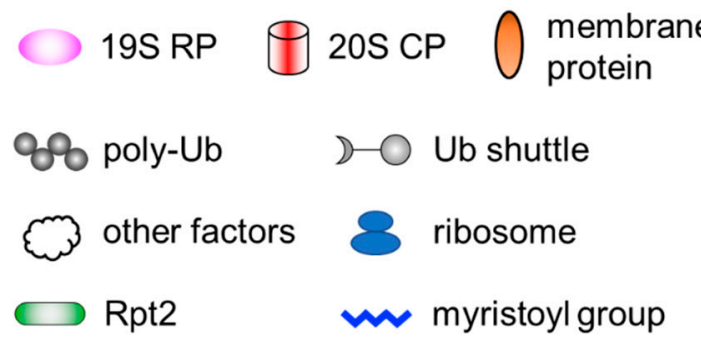

Figure 1. A simplified view of different modes of proteasome-membrane interaction. (A) In most cases, proteasomes attach to the membrane by directly or indirectly binding to resident membrane proteins, which may be modified by ubiquitination. (B) Neuronal membrane proteasomes (NMP) can degrade nascent, unfolded polypeptides. (C) Proteasomes tethered to the membrane via Nmyristoylated Rpt2, which is evolutionarily conserved from yeast to human. 


\subsection{Membrane Targeting of Proteasomes by N-Myristoylation}

A third means of targeting the proteasome to the membrane is through lipid modification. N-myristoylation of the Rpt2 subunit has been observed by mass spectrometry in multiple species, ranging from yeast to plants to mammals [154-161]. Typically, $\mathrm{N}$-myristoylation occurs co-translationally on nascent polypeptides still bound to the ribosome, where the 14-carbon saturated fatty acyl group is covalently linked to the second amino acid (almost always a Gly) after the initiator methionine is removed by methionyl aminopeptidase [162-164]. Notably, among all proteasome subunits of mammalian cells, Rpt2 is the only one that begins with Met-Gly, serving as the only site of the entire proteasome complex for N-myristoylation. This MG sequence of Rpt2 is strictly conserved from yeast to human, suggesting that Rpt 2 is likely to be myristoylated in all species. In yeast, myristoylated Rpt2 has been shown to target proteasomes to the nuclear envelope, which is required for nuclear protein quality control [156,157]. Blocking this modification with the Rpt2- $\Delta \mathrm{G}$ or Rpt2-G2A mutations causes mislocalization of nuclear proteasomes to the cytosol.

The role of Rpt 2 myristoylation in higher organisms has not been rigorously investigated, despite Rpt2 being one of the most abundantly myristoylated proteins in human cells [161]. Our recent work demonstrated that wild-type human Rpt2 proficient for myristoylation was found at the plasma membrane, with some distribution at membrane-bound organelles as well. Membrane localization was abolished by the same $\Delta G / G 2 A$ mutations of human Rpt2. However, in stark contrast with results from yeast, loss of Rpt2 myristoylation in mammalian cells led to Rpt2 enrichment in the nucleus [84]. A serendipitous finding was that myristoylation-mediated membrane association is a prerequisite for Rpt 2 phosphorylation at Tyr439 (Y439) by the tyrosine kinase Src, which itself is a well-established myristoylated protein tethered to the membrane [84,165]. Moreover, Rpt2-Y439 phosphorylation could be reversed by the phosphotyrosine phosphatase PTPN2 (also known as T cell PTP or TC-PTP). PTPN2 has multiple splicing isoforms. Rpt2-pY439 could only be dephosphorylated by the membrane-bound isoform of PTPN2 known as TC48, but not by the nuclear isoform TC45 [84]. Hence, the kinase, phosphatase and substrate are all placed in the same neighborhood confined by the membrane.

The biochemical consequence of Rpt2-Y439 phosphorylation is readily conceivable, as it is the very tyrosine residue within the highly conserved $\mathrm{HbYX}$ tail (hydrophobic residue-Tyr - any amino acid) of Rpt2 required for RP-CP association. Rpt2-Y439 is the most frequently detected pTyr site of all 19S subunits. The phosphorylation was seen in the developing rat brain but more evidently detected in cancer cells with hyperactive Src [84]. Src-mediated Rpt2-Y439 phosphorylation selectively inhibited the activity of membraneassociated proteasomes as demonstrated by a membrane-targeted reporter protein, Myr ${ }^{\mathrm{Rpt} 2}$ GFPodc. On the contrary, the Src-specific inhibitor saracatinib/AZD0530 blocked Y439 phosphorylation and enhanced proteasomal degradation of membrane-bound substrates. Importantly, this seemed to be an integral part of the anti-cancer effects of saracatinib, since cancer cells expressing the nonphosphorylatable Y439F mutant were more resistant to this drug, both in vitro and in vivo [84]. Thus, reversible phosphorylation of Rpt2-Y439 provides a unique example of localized regulation of membrane-associated proteasomes.

\section{Conclusions and Future Perspectives}

Proteasome localization is highly dynamic within the cell and may be remarkably heterogeneous between cell types. This is an important basis of compartmentalized protein degradation that is widely conserved through evolution. Nonetheless, we have seen differences between yeast and mammalian cells where the behavior and fate of the proteasome are differentially controlled by specific factors. We are just beginning to get in-depth understanding of intracellular proteasome targeting and trafficking in higher organisms, and it remains a daunting mission to obtain a complete picture of localized function and regulation of the proteasome across different cell types, species and growth/stress conditions. A 
yet more challenging task would be to confirm these findings in vivo and to develop new tools for "site-specific" manipulation of proteasomes at any particular location in a cell.

A prerequisite for achieving these goals is a deeper and better characterization of proteasome composition, modification, interactome and its microenvironment within a cell. Researchers have been empowered by state-of-the-art techniques, including proximity labeling (e.g., BioID/TurboID, APEX, PUP-IT) [166-168], quantitative proteomics, superresolution imaging and cryo-electron tomography (cryo-ET) [21,22,106,120,122] to probe and catalog the contents of proteasome-containing subcellular structures. Chemical biology approaches involving metabolic labeling, click chemistry, genetic code expansion and cross-linking mass spectrometry (XL-MS) have provided critical insights into proteasome modification and assembly [83,161,169-171]. Commonly used reporter proteins (e.g., GFPu, GFPodc, $\mathrm{Ub}^{\mathrm{G} 76 \mathrm{~V}}$-GFP, UBL-CP8-35) can be engineered to reflect local proteasome activity at defined compartments $[84,108,172,173]$, while knock-in mice bearing fluorescence proteintagged proteasome subunits would be valuable to monitor proteasome distribution and dynamics in vivo [174]. With classic yeast genetics and CRISPR screens, many more regulators of the proteasome are expected to be uncovered [93,114].

Finally, some further possibilities may be speculated. 1. In addition to the above discussed, what other mechanisms may be used for proteasome targeting? Can we alter proteasome localization (and function) pharmacologically, optically, mechanically, magnetically or acoustically [175]? Does lipid modification (i.e., N-myristoylation) promote exosomal secretion of the proteasome, as has been shown with palmitoylated ACE2 [176]? Can we design "Proteasome-TACs" that recruit proteasomes directly to the substrates (or vice versa) for therapeutic use? A recently discovered small circular RNA seemed to do precisely that [149]. Along this line, since proteasome subunits have been identified as RNA-binding proteins $[177,178]$, can RNAs act as molecular tethers between the proteasome and chromatin or other proteins [179]? 2. As mentioned earlier, cancer cells show reduced SIPAN formation [109], and tyrosine phosphorylation of membrane-bound Rpt2 is relevant to the anti-cancer effect of saracatinib [84]. This makes one wonder whether proteasome (mis)localization can be considered as a biomarker for disease diagnosis and treatment. Moreover, it is unclear whether subcellular localization of the proteasome is altered in multiple myeloma patients after proteasome inhibitor treatment, or in patients with proteasome-associated autoinflammatory syndrome (PRAAS) who carry congenital mutations in proteasome genes $[180,181]$. Relocation of the proteasome may cause changes to the local proteome and rewire intracellular signaling, which may lead to a different kind of proteasome-oriented therapy.

Funding: X.G. was funded by Natural Science Foundation of China (grant numbers 31870762, 32071257) and Zhejiang Provincial Natural Science Foundation of China (grant number LR18C050001).

Institutional Review Board Statement: Not applicable.

Informed Consent Statement: Not applicable.

Data Availability Statement: Not applicable.

Conflicts of Interest: The author declares no conflict of interest. The funders had no role in the writing of the manuscript.

\section{References}

1. Collins, G.A.; Goldberg, A.L. The Logic of the 26S Proteasome. Cell 2017, 169, 792-806. [CrossRef] [PubMed]

2. Bard, J.A.M.; Goodall, E.A.; Greene, E.R.; Jonsson, E.; Dong, K.C.; Martin, A. Structure and function of the $26 \mathrm{~S}$ proteasome. Annu. Rev. Biochem. 2018, 87, 697-724. [CrossRef] [PubMed]

3. Budenholzer, L.; Cheng, C.L.; Li, Y.; Hochstrasser, M. Proteasome structure and assembly. J. Mol. Biol. 2017, 429, 3500-3524. [CrossRef] [PubMed]

4. Murata, S.; Yashiroda, H.; Tanaka, K. Molecular mechanisms of proteasome assembly. Nat. Rev. Mol. Cell Biol. 2009, 10, 104-115. [CrossRef] [PubMed]

5. Finley, D. Recognition and processing of ubiquitin-protein conjugates by the proteasome. Annu. Rev. Biochem. 2009, 78, 477-513. [CrossRef] [PubMed] 
6. Mao, Y. Structure, dynamics and function of the $26 \mathrm{~S}$ proteasome. Subcell Biochem. 2021, 96, 1-151. [PubMed]

7. Finley, D.; Prado, M.A. The proteasome and its network: Engineering for adaptability. Cold Spring Harb. Perspect. Biol. 2020, 12, a033985. [CrossRef] [PubMed]

8. Schmidt, M.; Finley, D. Regulation of proteasome activity in health and disease. Biochim. Biophys. Acta 2014, 1843, 13-25. [CrossRef] [PubMed]

9. Hershko, A.; Ciechanover, A. The ubiquitin system. Annu. Rev. Biochem. 1998, 67, 425-479. [CrossRef]

10. Marshall, R.S.; Vierstra, R.D. Dynamic regulation of the 26S proteasome: From synthesis to degradation. Front. Mol. Biosci. 2019, 6, 40. [CrossRef]

11. de la Pena, A.H.; Goodall, E.A.; Gates, S.N.; Lander, G.C.; Martin, A. Substrate-engaged 26S proteasome structures reveal mechanisms for ATP-hydrolysis-driven translocation. Science 2018, 362, eaav0725. [CrossRef] [PubMed]

12. Dong, Y.; Zhang, S.; Wu, Z.; Li, X.; Wang, W.L.; Zhu, Y.; Stoilova-McPhie, S.; Lu, Y.; Finley, D.; Mao, Y. Cryo-EM structures and dynamics of substrate-engaged human $26 \mathrm{~S}$ proteasome. Nature 2019, 565, 49-55. [CrossRef] [PubMed]

13. Goldberg, A.L. Development of proteasome inhibitors as research tools and cancer drugs. J. Cell Biol. 2012, 199, 583-588. [CrossRef] [PubMed]

14. Kisselev, A.F. Site-specific proteasome inhibitors. Biomolecules 2022, 12, 54. [CrossRef] [PubMed]

15. Tundo, G.R.; Sbardella, D.; Santoro, A.M.; Coletta, A.; Oddone, F.; Grasso, G.; Milardi, D.; Lacal, P.M.; Marini, S.; Purrello, R.; et al. The proteasome as a druggable target with multiple therapeutic potentialities: Cutting and non-cutting edges. Pharmacol. Ther. 2020, 213, 107579. [CrossRef] [PubMed]

16. Leestemaker, Y.; de Jong, A.; Witting, K.F.; Penning, R.; Schuurman, K.; Rodenko, B.; Zaal, E.A.; van de Kooij, B.; Laufer, S.; Heck, A.J.R.; et al. Proteasome activation by small molecules. Cell Chem. Biol. 2017, 24, 725-736.e7. [CrossRef] [PubMed]

17. Goldberg, A.L.; Kim, H.T.; Lee, D.; Collins, G.A. Mechanisms that activate $26 \mathrm{~S}$ proteasomes and enhance protein degradation. Biomolecules 2021, 11, 779. [CrossRef]

18. Njomen, E.; Tepe, J.J. Proteasome activation as a new therapeutic approach to target proteotoxic disorders. J. Med. Chem. 2019, 62, 6469-6481. [CrossRef]

19. He, Y.; Guo, X.; Yu, Z.H.; Wu, L.; Gunawan, A.M.; Zhang, Y.; Dixon, J.E.; Zhang, Z.Y. A potent and selective inhibitor for the UBLCP1 proteasome phosphatase. Bioorg. Med. Chem. 2015, 23, 2798-2809. [CrossRef]

20. Besche, H.C.; Goldberg, A.L. Affinity purification of mammalian $26 \mathrm{~S}$ proteasomes using an ubiquitin-like domain. Methods Mol. Biol. 2012, 832, 423-432.

21. Pack, C.G.; Yukii, H.; Toh-e, A.; Kudo, T.; Tsuchiya, H.; Kaiho, A.; Sakata, E.; Murata, S.; Yokosawa, H.; Sako, Y.; et al. Quantitative live-cell imaging reveals spatio-temporal dynamics and cytoplasmic assembly of the $26 \mathrm{~S}$ proteasome. Nat. Commun. 2014, 5, 3396. [CrossRef]

22. Asano, S.; Fukuda, Y.; Beck, F.; Aufderheide, A.; Forster, F.; Danev, R.; Baumeister, W. Proteasomes. A molecular census of 26S proteasomes in intact neurons. Science 2015, 347, 439-442. [PubMed]

23. Chang, J.T.; Ciocca, M.L.; Kinjyo, I.; Palanivel, V.R.; McClurkin, C.E.; Dejong, C.S.; Mooney, E.C.; Kim, J.S.; Steinel, N.C.; Oliaro, J.; et al. Asymmetric proteasome segregation as a mechanism for unequal partitioning of the transcription factor T-bet during $\mathrm{T}$ lymphocyte division. Immunity 2011, 34, 492-504. [CrossRef] [PubMed]

24. Chang, J.T.; Palanivel, V.R.; Kinjyo, I.; Schambach, F.; Intlekofer, A.M.; Banerjee, A.; Longworth, S.A.; Vinup, K.E.; Mrass, P.; Oliaro, J.; et al. Asymmetric T lymphocyte division in the initiation of adaptive immune responses. Science 2007, 315, 1687-1691. [CrossRef]

25. Moore, D.L.; Pilz, G.A.; Araúzo-Bravo, M.J.; Barral, Y.; Jessberger, S. A mechanism for the segregation of age in mammalian neural stem cells. Science 2015, 349, 1334-1338. [CrossRef] [PubMed]

26. Ogrodnik, M.; Salmonowicz, H.; Brown, R.; Turkowska, J.; Średniawa, W.; Pattabiraman, S.; Amen, T.; Abraham, A.C.; Eichler, N.; Lyakhovetsky, R.; et al. Dynamic JUNQ inclusion bodies are asymmetrically inherited in mammalian cell lines through the asymmetric partitioning of vimentin. Proc. Natl. Acad. Sci. USA 2014, 111, 8049-8054. [CrossRef]

27. Rivett, A.J. Intracellular distribution of proteasomes. Curr. Opin. Immunol. 1998, 10, 110-114. [CrossRef]

28. Wojcik, C.; DeMartino, G.N. Intracellular localization of proteasomes. Int. J. Biochem. Cell Biol. 2003, 35, 579-589. [CrossRef]

29. Pines, J.; Lindon, C. Proteolysis: Anytime, any place, anywhere? Nat. Cell Biol. 2005, 7, 731-735. [CrossRef]

30. Laporte, D.; Salin, B.; Daignan-Fornier, B.; Sagot, I. Reversible cytoplasmic localization of the proteasome in quiescent yeast cells. J. Cell Biol. 2008, 181, 737-745. [CrossRef]

31. Marshall, R.S.; Vierstra, R.D. Proteasome storage granules protect proteasomes from autophagic degradation upon carbon starvation. eLife 2018, 7, e34532. [CrossRef] [PubMed]

32. Saitoh, Y.; Sawada, H.; Yokosawa, H. High-molecular-weight protease complexes (proteasomes) of sperm of the ascidian, Halocynthia roretzi: Isolation, characterization, and physiological roles in fertilization. Dev. Biol. 1993, 158, 238-244. [CrossRef] [PubMed]

33. Sawada, H.; Pinto, M.R.; De Santis, R. Participation of sperm proteasome in fertilization of the phlebobranch ascidian Ciona intestinalis. Mol. Reprod. Dev. 1998, 50, 493-498. [CrossRef]

34. Sawada, H.; Sakai, N.; Abe, Y.; Tanaka, E.; Takahashi, Y.; Fujino, J.; Kodama, E.; Takizawa, S.; Yokosawa, H. Extracellular ubiquitination and proteasome-mediated degradation of the ascidian sperm receptor. Proc. Natl. Acad. Sci. USA 2002, 99, 1223-1228. [CrossRef] [PubMed] 
35. Wada, M.; Kosaka, M.; Saito, S.; Sano, T.; Tanaka, K.; Ichihara, A. Serum concentration and localization in tumor cells of proteasomes in patients with hematologic malignancy and their pathophysiologic significance. J. Lab. Clin. Med. 1993, 121, 215-223. [PubMed]

36. Choi, W.H.; Kim, S.; Park, S.; Lee, M.J. Concept and application of circulating proteasomes. Exp. Mol. Med. 2021, 53, 1539-1546. [CrossRef] [PubMed]

37. Dwivedi, V.; Yaniv, K.; Sharon, M. Beyond cells: The extracellular circulating 20 S proteasomes. Biochim. Biophys. Acta Mol. Basis Dis. 2021, 1867, 166041. [CrossRef]

38. Sixt, S.U.; Dahlmann, B. Extracellular, circulating proteasomes and ubiquitin-incidence and relevance. Biochim. Biophys. Acta 2008, 1782, 817-823. [CrossRef]

39. Kulichkova, V.A.; Artamonova, T.O.; Lyublinskaya, O.G.; Khodorkovskii, M.A.; Tomilin, A.N.; Tsimokha, A.S. Proteomic analysis of affinity-purified extracellular proteasomes reveals exclusively 20S complexes. Oncotarget 2017, 8, 102134-102149. [CrossRef]

40. Tsimokha, A.S.; Zaykova, J.J.; Bottrill, A.; Barlev, N.A. Extracellular proteasomes are deficient in 19S subunits as revealed by iTRAQ quantitative proteomics. J. Cell Physiol. 2017, 232, 842-851. [CrossRef]

41. Kalluri, R.; LeBleu, V.S. The biology, function, and biomedical applications of exosomes. Science 2020, 367, eaau6977. [CrossRef] [PubMed]

42. Breckel, C.A.; Hochstrasser, M. Ubiquitin ligase redundancy and nuclear-cytoplasmic localization in yeast protein quality control. Biomolecules 2021, 11, 1821. [CrossRef] [PubMed]

43. Hirayama, S.; Sugihara, M.; Morito, D.; Iemura, S.I.; Natsume, T.; Murata, S.; Nagata, K. Nuclear export of ubiquitinated proteins via the UBIN-POST system. Proc. Natl. Acad. Sci. USA 2018, 115, e4199-e4208. [CrossRef] [PubMed]

44. Kopito, R.R. Aggresomes, inclusion bodies and protein aggregation. Trends Cell Biol. 2000, 10, 524-530. [CrossRef]

45. Miller, S.B.; Ho, C.T.; Winkler, J.; Khokhrina, M.; Neuner, A.; Mohamed, M.Y.; Guilbride, D.L.; Richter, K.; Lisby, M.; Schiebel, E.; et al. Compartment-specific aggregases direct distinct nuclear and cytoplasmic aggregate deposition. EMBO J. 2015, 34, 778-797. [CrossRef] [PubMed]

46. Escusa-Toret, S.; Vonk, W.I.; Frydman, J. Spatial sequestration of misfolded proteins by a dynamic chaperone pathway enhances cellular fitness during stress. Nat. Cell Biol. 2013, 15, 1231-1243. [CrossRef]

47. Miller, S.B.; Mogk, A.; Bukau, B. Spatially organized aggregation of misfolded proteins as cellular stress defense strategy. J. Mol. Biol. 2015, 427, 1564-1574. [CrossRef]

48. Sontag, E.M.; Samant, R.S.; Frydman, J. Mechanisms and functions of spatial protein quality control. Annu. Rev. Biochem. 2017, 86, 97-122. [CrossRef]

49. Enam, C.; Geffen, Y.; Ravid, T.; Gardner, R.G. Protein quality control degradation in the nucleus. Annu. Rev. Biochem. 2018, 87, 725-749. [CrossRef]

50. Kaganovich, D.; Kopito, R.; Frydman, J. Misfolded proteins partition between two distinct quality control compartments. Nature 2008, 454, 1088-1095. [CrossRef]

51. Wendler, P.; Enenkel, C. Nuclear transport of yeast proteasomes. Front. Mol. Biosci. 2019, 6, 34. [CrossRef] [PubMed]

52. Enenkel, C. Nuclear transport of yeast proteasomes. Biomolecules 2014, 4, 940-955. [CrossRef] [PubMed]

53. Burcoglu, J.; Zhao, L.; Enenkel, C. Nuclear import of yeast proteasomes. Cells 2015, 4, 387-405. [CrossRef] [PubMed]

54. Enenkel, C. Proteasome dynamics. Biochim. Biophys. Acta 2014, 1843, 39-46. [CrossRef]

55. Chowdhury, M.; Enenkel, C. Intracellular dynamics of the ubiquitin-proteasome-system. F1000Research 2015, 4, 367. [CrossRef]

56. Bassermann, F.; Eichner, R.; Pagano, M. The ubiquitin proteasome system-implications for cell cycle control and the targeted treatment of cancer. Biochim. Biophys. Acta 2014, 1843, 150-162. [CrossRef]

57. Craney, A.; Rape, M. Dynamic regulation of ubiquitin-dependent cell cycle control. Curr. Opin. Cell Biol. 2013, 25, 704-710. [CrossRef]

58. Vujin, A.; Zetka, M. The proteasome enters the meiotic prophase fray. Bioessays 2017, 39, 38. [CrossRef]

59. Ahuja, J.S.; Sandhu, R.; Mainpal, R.; Lawson, C.; Henley, H.; Hunt, P.A.; Yanowitz, J.L.; Börner, G.V. Control of meiotic pairing and recombination by chromosomally tethered 26 S proteasome. Science 2017, 355, 408-411. [CrossRef]

60. Rao, H.B.; Qiao, H.; Bhatt, S.K.; Bailey, L.R.; Tran, H.D.; Bourne, S.L.; Qiu, W.; Deshpande, A.; Sharma, A.N.; Beebout, C.J.; et al. A SUMO-ubiquitin relay recruits proteasomes to chromosome axes to regulate meiotic recombination. Science 2017, 355, 403-407. [CrossRef]

61. McCann, T.S.; Tansey, W.P. Functions of the proteasome on chromatin. Biomolecules 2014, 4, 1026-1044. [CrossRef] [PubMed]

62. Zou, C.; Mallampalli, R.K. Regulation of histone modifying enzymes by the ubiquitin-proteasome system. Biochim. Biophys. Acta 2014, 1843, 694-702. [CrossRef] [PubMed]

63. Vaughan, R.M.; Kupai, A.; Rothbart, S.B. Chromatin regulation through ubiquitin and ubiquitin-like histone modifications. Trends Biochem. Sci. 2021, 46, 258-269. [CrossRef] [PubMed]

64. Bach, S.V.; Hegde, A.N. The proteasome and epigenetics: Zooming in on histone modifications. Biomol. Concepts 2016, 7, 215-227. [CrossRef] [PubMed]

65. Baldin, V.; Militello, M.; Thomas, Y.; Doucet, C.; Fic, W.; Boireau, S.; Jariel-Encontre, I.; Piechaczyk, M.; Bertrand, E.; Tazi, J.; et al A novel role for PA28gamma-proteasome in nuclear speckle organization and SR protein trafficking. Mol. Biol. Cell 2008, 19, 1706-1716. [CrossRef] [PubMed] 
66. Thapa, P.; Shanmugam, N.; Pokrzywa, W. Ubiquitin signaling regulates RNA biogenesis, processing, and metabolism. Bioessays 2020, 42, e1900171. [CrossRef] [PubMed]

67. Krogan, N.J.; Lam, M.H.; Fillingham, J.; Keogh, M.C.; Gebbia, M.; Li, J.; Datta, N.; Cagney, G.; Buratowski, S.; Emili, A.; et al Proteasome involvement in the repair of DNA double-strand breaks. Mol. Cell 2004, 16, 1027-1034. [CrossRef]

68. Silverman, J.S.; Skaar, J.R.; Pagano, M. SCF ubiquitin ligases in the maintenance of genome stability. Trends Biochem. Sci. 2012, 37, 66-73. [CrossRef]

69. Ramadan, K.; Meerang, M. Degradation-linked ubiquitin signal and proteasome are integral components of DNA double strand break repair: New perspectives for anti-cancer therapy. FEBS Lett. 2011, 585, 2868-2875. [CrossRef] [PubMed]

70. von Mikecz, A. The nuclear ubiquitin-proteasome system. J. Cell Sci. 2006, 119, 1977-1984. [CrossRef]

71. Guo, X.; Engel, J.L.; Xiao, J.; Tagliabracci, V.S.; Wang, X.; Huang, L.; Dixon, J.E. UBLCP1 is a 26S proteasome phosphatase that regulates nuclear proteasome activity. Proc. Natl. Acad. Sci. USA 2011, 108, 18649-18654. [CrossRef] [PubMed]

72. Wójcik, C.; Tanaka, K.; Paweletz, N.; Naab, U.; Wilk, S. Proteasome activator (PA28) subunits, alpha, beta and gamma (Ki antigen) in NT2 neuronal precursor cells and HeLa S3 cells. Eur. J. Cell Biol. 1998, 77, 151-160. [CrossRef]

73. Qian, M.X.; Pang, Y.; Liu, C.H.; Haratake, K.; Du, B.Y.; Ji, D.Y.; Wang, G.F.; Zhu, Q.Q.; Song, W.; Yu, Y.; et al. Acetylation-mediated proteasomal degradation of core histones during DNA repair and spermatogenesis. Cell 2013, 153, 1012-1024. [CrossRef] [PubMed]

74. Jonik-Nowak, B.; Menneteau, T.; Fesquet, D.; Baldin, V.; Bonne-Andrea, C.; Méchali, F.; Fabre, B.; Boisguerin, P.; de Rossi, S.; Henriquet, C.; et al. PIP30/FAM192A is a novel regulator of the nuclear proteasome activator PA28 $\gamma$. Proc. Natl. Acad. Sci. USA 2018, 115, e6477-e6486. [CrossRef]

75. Ustrell, V.; Hoffman, L.; Pratt, G.; Rechsteiner, M. PA200, a nuclear proteasome activator involved in DNA repair. EMBO J. 2002, 21, 3516-3525. [CrossRef] [PubMed]

76. Tsuchiya, H.; Arai, N.; Tanaka, K.; Saeki, Y. Cytoplasmic proteasomes are not indispensable for cell growth in Saccharomyces cerevisiae. Biochem. Biophys. Res. Commun. 2013, 436, 372-376. [CrossRef] [PubMed]

77. Tanaka, K.; Yoshimura, T.; Tamura, T.; Fujiwara, T.; Kumatori, A.; Ichihara, A. Possible mechanism of nuclear translocation of proteasomes. FEBS Lett. 1990, 271, 41-46. [CrossRef]

78. Nederlof, P.M.; Wang, H.R.; Baumeister, W. Nuclear localization signals of human and Thermoplasma proteasomal alpha subunits are functional in vitro. Proc. Natl. Acad. Sci. USA 1995, 92, 12060-12064. [CrossRef] [PubMed]

79. Knuehl, C.; Seelig, A.; Brecht, B.; Henklein, P.; Kloetzel, P.M. Functional analysis of eukaryotic 20S proteasome nuclear localization signal. Exp. Cell Res. 1996, 225, 67-74. [CrossRef]

80. Wu, W.; Sahara, K.; Hirayama, S.; Zhao, X.; Watanabe, A.; Hamazaki, J.; Yashiroda, H.; Murata, S. PAC1-PAC2 proteasome assembly chaperone retains the core $\alpha 4-\alpha 7$ assembly intermediates in the cytoplasm. Genes Cells 2018, 23, 839-848. [CrossRef]

81. Wang, H.R.; Kania, M.; Baumeister, W.; Nederlof, P.M. Import of human and Thermoplasma $20 \mathrm{~S}$ proteasomes into nuclei of HeLa cells requires functional NLS sequences. Eur. J. Cell Biol. 1997, 73, 105-113. [PubMed]

82. Wendler, P.; Lehmann, A.; Janek, K.; Baumgart, S.; Enenkel, C. The bipartite nuclear localization sequence of Rpn2 is required for nuclear import of proteasomal base complexes via karyopherin alphabeta and proteasome functions. J. Biol. Chem. 2004, 279, 37751-37762. [CrossRef] [PubMed]

83. Liu, X.; Xiao, W.; Zhang, Y.; Wiley, S.E.; Zuo, T.; Zheng, Y.; Chen, N.; Chen, L.; Wang, X.; Zheng, Y.; et al. Reversible phosphorylation of Rpn1 regulates 26 S proteasome assembly and function. Proc. Natl. Acad. Sci. USA 2020, 117, 328-336. [CrossRef] [PubMed]

84. Chen, L.; Zhang, Y.; Shu, X.; Chen, Q.; Wei, T.; Wang, H.; Wang, X.; Wu, Q.; Zhang, X.; Liu, X.; et al. Proteasome regulation by reversible tyrosine phosphorylation at the membrane. Oncogene 2021, 40, 1942-1956. [CrossRef]

85. Savulescu, A.F.; Shorer, H.; Kleifeld, O.; Cohen, I.; Gruber, R.; Glickman, M.H.; Harel, A. Nuclear import of an intact preassembled proteasome particle. Mol. Biol. Cell 2011, 22, 880-891. [CrossRef]

86. Zimmerli, C.E.; Allegretti, M.; Rantos, V.; Goetz, S.K.; Obarska-Kosinska, A.; Zagoriy, I.; Halavatyi, A.; Hummer, G.; Mahamid, J.; Kosinski, J.; et al. Nuclear pores dilate and constrict in cellulo. Science 2021, 374, eabd9776. [CrossRef]

87. Akey, C.W.; Singh, D.; Ouch, C.; Echeverria, I.; Nudelman, I.; Varberg, J.M.; Yu, Z.; Fang, F.; Shi, Y.; Wang, J.; et al. Comprehensive structure and functional adaptations of the yeast nuclear pore complex. Cell 2022, 185, 361-378.e25. [CrossRef]

88. Chen, L.; Romero, L.; Chuang, S.M.; Tournier, V.; Joshi, K.K.; Lee, J.A.; Kovvali, G.; Madura, K. Sts1 plays a key role in targeting proteasomes to the nucleus. J. Biol. Chem. 2011, 286, 3104-3118. [CrossRef]

89. Tabb, M.M.; Tongaonkar, P.; Vu, L.; Nomura, M. Evidence for separable functions of Srp1p, the yeast homolog of importin alpha (Karyopherin alpha): Role for Srp1p and Sts1p in protein degradation. Mol. Cell Biol. 2000, 20, 6062-6073. [CrossRef]

90. Budenholzer, L.; Breckel, C.; Hickey, C.M.; Hochstrasser, M. The Sts1 nuclear import adapter uses a non-canonical bipartite nuclear localization signal and is directly degraded by the proteasome. J. Cell Sci. 2020, 133, jcs236158. [CrossRef]

91. Takeda, K.; Tonthat, N.K.; Glover, T.; Xu, W.; Koonin, E.V.; Yanagida, M.; Schumacher, M.A. Implications for proteasome nuclear localization revealed by the structure of the nuclear proteasome tether protein Cut8. Proc. Natl. Acad. Sci. USA 2011, 108, 16950-16955. [CrossRef] [PubMed]

92. Takeda, K.; Yanagida, M. Regulation of nuclear proteasome by Rhp6/Ubc2 through ubiquitination and destruction of the sensor and anchor Cut8. Cell 2005, 122, 393-405. [CrossRef] [PubMed] 
93. de Almeida, M.; Hinterndorfer, M.; Brunner, H.; Grishkovskaya, I.; Singh, K.; Schleiffer, A.; Jude, J.; Deswal, S.; Kalis, R.; Vunjak, M.; et al. AKIRIN2 controls the nuclear import of proteasomes in vertebrates. Nature 2021, 599, 491-496. [CrossRef] [PubMed]

94. Palacios, V.; Kimble, G.C.; Tootle, T.L.; Buszczak, M. Importin-9 regulates chromosome segregation and packaging in Drosophila germ cells. J. Cell Sci. 2021, 134, jcs258391. [CrossRef] [PubMed]

95. Chen, X.; Walters, K.J. Nuclear destruction: A suicide mission by AKIRIN2 brings intact proteasomes into the nucleus. Mol. Cell 2022, 82, 13-14. [CrossRef] [PubMed]

96. Dominguez, D.; Tsai, Y.H.; Gomez, N.; Jha, D.K.; Davis, I.; Wang, Z. A high-resolution transcriptome map of cell cycle reveals novel connections between periodic genes and cancer. Cell Res. 2016, 26, 946-962. [CrossRef] [PubMed]

97. Amm, I.; Sommer, T.; Wolf, D.H. Protein quality control and elimination of protein waste: The role of the ubiquitin-proteasome system. Biochim. Biophys. Acta 2014, 1843, 182-196. [CrossRef] [PubMed]

98. Karmon, O.; Ben Aroya, S. Spatial organization of proteasome aggregates in the regulation of proteasome homeostasis. Front. Mol. Biosci. 2019, 6, 150. [CrossRef] [PubMed]

99. Boronat, S.; Cabrera, M.; Hidalgo, E. Spatial sequestration of misfolded proteins as an active chaperone-mediated process during heat stress. Curr. Genet. 2021, 67, 237-243. [CrossRef] [PubMed]

100. Hofmann, S.; Kedersha, N.; Anderson, P.; Ivanov, P. Molecular mechanisms of stress granule assembly and disassembly. Biochim. Biophys. Acta Mol. Cell Res. 2021, 1868, 118876. [CrossRef]

101. Ruan, L.; Zhou, C.; Jin, E.; Kucharavy, A.; Zhang, Y.; Wen, Z.; Florens, L.; Li, R. Cytosolic proteostasis through importing of misfolded proteins into mitochondria. Nature 2017, 543, 443-446. [CrossRef] [PubMed]

102. Liu, W.; Duan, X.; Fang, X.; Shang, W.; Tong, C. Mitochondrial protein import regulates cytosolic protein homeostasis and neuronal integrity. Autophagy 2018, 14, 1293-1309. [CrossRef] [PubMed]

103. Turakhiya, A.; Meyer, S.R.; Marincola, G.; Böhm, S.; Vanselow, J.T.; Schlosser, A.; Hofmann, K.; Buchberger, A. ZFAND1 Recruits p97 and the 26S Proteasome to Promote the Clearance of Arsenite-Induced Stress Granules. Mol. Cell 2018, 70, 906-919.e7. [CrossRef] [PubMed]

104. Johnston, J.A.; Ward, C.L.; Kopito, R.R. Aggresomes: A cellular response to misfolded proteins. J. Cell Biol. 1998, 143, 1883-1898. [CrossRef] [PubMed]

105. Au, C.E.; Hermo, L.; Byrne, E.; Smirle, J.; Fazel, A.; Kearney, R.E.; Smith, C.E.; Vali, H.; Fernandez-Rodriguez, J.; Simon, P.H.; et al. Compartmentalization of membrane trafficking, glucose transport, glycolysis, actin, tubulin and the proteasome in the cytoplasmic droplet/Hermes body of epididymal sperm. Open Biol. 2015, 5, 150080. [CrossRef]

106. Yasuda, S.; Tsuchiya, H.; Kaiho, A.; Guo, Q.; Ikeuchi, K.; Endo, A.; Arai, N.; Ohtake, F.; Murata, S.; Inada, T.; et al. Stress- and ubiquitylation-dependent phase separation of the proteasome. Nature 2020, 578, 296-300. [CrossRef] [PubMed]

107. Lee, J.; Le, L.; Kim, E.; Lee, M.J. Formation of non-nucleoplasmic proteasome foci during the late stage of hyperosmotic stress. Cells 2021, 10, 2493. [CrossRef]

108. Fu, A.; Cohen-Kaplan, V.; Avni, N.; Livneh, I.; Ciechanover, A. p62-containing, proteolytically active nuclear condensates, increase the efficiency of the ubiquitin-proteasome system. Proc. Natl. Acad. Sci. USA 2021, 118, e2107321118. [CrossRef]

109. Uriarte, M.; Sen Nkwe, N.; Tremblay, R.; Ahmed, O.; Messmer, C.; Mashtalir, N.; Barbour, H.; Masclef, L.; Voide, M.; Viallard, C.; et al. Starvation-induced proteasome assemblies in the nucleus link amino acid supply to apoptosis. Nat. Commun. 2021, 12, 6984. [CrossRef]

110. Alberti, S.; Gladfelter, A.; Mittag, T. Considerations and challenges in studying liquid-liquid phase separation and biomolecular condensates. Cell 2019, 176, 419-434. [CrossRef]

111. Song, A.; Hazlett, Z.; Abeykoon, D.; Dortch, J.; Dillon, A.; Curtiss, J.; Martinez, S.B.; Hill, C.P.; Yu, C.; Huang, L.; et al. Branched ubiquitin chain binding and deubiquitination by UCH37 facilitate proteasome clearance of stress-induced inclusions. eLife 2021, 10, e72798. [CrossRef] [PubMed]

112. Deol, K.K.; Crowe, S.O.; Du, J.; Bisbee, H.A.; Guenette, R.G.; Strieter, E.R. Proteasome-bound UCH37/UCHL5 debranches ubiquitin chains to promote degradation. Mol. Cell 2020, 80, 796-809.e9. [CrossRef] [PubMed]

113. Lee, S.H.; Park, Y.; Yoon, S.K.; Yoon, J.B. Osmotic stress inhibits proteasome by p38 MAPK-dependent phosphorylation. J. Biol. Chem. 2010, 285, 41280-41289. [CrossRef]

114. Gu, Z.C.; Wu, E.; Sailer, C.; Jando, J.; Styles, E.; Eisenkolb, I.; Kuschel, M.; Bitschar, K.; Wang, X.; Huang, L.; et al. Ubiquitin orchestrates proteasome dynamics between proliferation and quiescence in yeast. Mol. Biol. Cell 2017, 28, 2479-2491. [CrossRef] [PubMed]

115. Waite, K.A.; Burris, A.; Vontz, G.; Lang, A.; Roelofs, J. Proteaphagy is specifically regulated and requires factors dispensable for general autophagy. J. Biol. Chem. 2021, 298, 101494. [CrossRef]

116. Kinoshita, M.; Hamakubo, T.; Fukui, I.; Murachi, T.; Toyohara, H. Significant amount of multicatalytic proteinase identified on membrane from human erythrocyte. J. Biochem. 1990, 107, 440-444. [CrossRef]

117. Rivett, A.J.; Palmer, A.; Knecht, E. Electron microscopic localization of the multicatalytic proteinase complex in rat liver and in cultured cells. J. Histochem. Cytochem. 1992, 40, 1165-1172. [CrossRef]

118. Kalies, K.U.; Allan, S.; Sergeyenko, T.; Kröger, H.; Römisch, K. The protein translocation channel binds proteasomes to the endoplasmic reticulum membrane. EMBO J. 2005, 24, 2284-2293. [CrossRef]

119. Kaiser, M.L.; Römisch, K. Proteasome 19S RP binding to the Sec61 channel plays a key role in ERAD. PLoS ONE 2015, 10, e0117260. [CrossRef] 
120. Albert, S.; Wietrzynski, W.; Lee, C.W.; Schaffer, M.; Beck, F.; Schuller, J.M.; Salomé, P.A.; Plitzko, J.M.; Baumeister, W.; Engel, B.D. Direct visualization of degradation microcompartments at the ER membrane. Proc. Natl. Acad. Sci. USA 2020, 117, 1069-1080. [CrossRef]

121. Enenkel, C.; Lehmann, A.; Kloetzel, P.M. Subcellular distribution of proteasomes implicates a major location of protein degradation in the nuclear envelope-ER network in yeast. EMBO J. 1998, 17, 6144-6154. [CrossRef] [PubMed]

122. Albert, S.; Schaffer, M.; Beck, F.; Mosalaganti, S.; Asano, S.; Thomas, H.F.; Plitzko, J.M.; Beck, M.; Baumeister, W.; Engel, B.D. Proteasomes tether to two distinct sites at the nuclear pore complex. Proc. Natl. Acad. Sci. USA 2017, 114, 13726-13731. [CrossRef] [PubMed]

123. Nakagawa, T.; Shirane, M.; Iemura, S.; Natsume, T.; Nakayama, K.I. Anchoring of the $26 \mathrm{~S}$ proteasome to the organellar membrane by FKBP38. Genes Cells 2007, 12, 709-719. [CrossRef] [PubMed]

124. Fricke, B.; Heink, S.; Steffen, J.; Kloetzel, P.M.; Krüger, E. The proteasome maturation protein POMP facilitates major steps of 20S proteasome formation at the endoplasmic reticulum. EMBO Rep. 2007, 8, 1170-1175. [CrossRef] [PubMed]

125. Schmidt, O.; Weyer, Y.; Baumann, V.; Widerin, M.A.; Eising, S.; Angelova, M.; Schleiffer, A.; Kremser, L.; Lindner, H.; Peter, M.; et al. Endosome and Golgi-associated degradation (EGAD) of membrane proteins regulates sphingolipid metabolism. EMBO J. 2019, 38, e101433. [CrossRef] [PubMed]

126. Eisenberg-Lerner, A.; Benyair, R.; Hizkiahou, N.; Nudel, N.; Maor, R.; Kramer, M.P.; Shmueli, M.D.; Zigdon, I.; Cherniavsky Lev, M.; Ulman, A.; et al. Golgi organization is regulated by proteasomal degradation. Nat. Commun. 2020, 11, 409. [CrossRef]

127. Gorbea, C.; Goellner, G.M.; Teter, K.; Holmes, R.K.; Rechsteiner, M. Characterization of mammalian Ecm29, a 26 S proteasomeassociated protein that localizes to the nucleus and membrane vesicles. J. Biol. Chem. 2004, 279, 54849-54861. [CrossRef]

128. Gorbea, C.; Pratt, G.; Ustrell, V.; Bell, R.; Sahasrabudhe, S.; Hughes, R.E.; Rechsteiner, M. A protein interaction network for Ecm29 links the $26 \mathrm{~S}$ proteasome to molecular motors and endosomal components. J. Biol. Chem. 2010, 285, 31616-31633. [CrossRef]

129. Lee, M.; Liu, Y.C.; Chen, C.; Lu, C.H.; Lu, S.T.; Huang, T.N.; Hsu, M.T.; Hsueh, Y.P.; Cheng, P.L. Ecm29-mediated proteasomal distribution modulates excitatory GABA responses in the developing brain. J. Cell Biol. 2020, 219, e201903033. [CrossRef] [PubMed]

130. Ibañez-Vega, J.; Del Valle, F.; Sáez, J.J.; Guzman, F.; Diaz, J.; Soza, A.; Yuseff, M.I. Ecm29-dependent proteasome localization regulates cytoskeleton remodeling at the immune synapse. Front. Cell Dev. Biol. 2021, 9, 650817. [CrossRef] [PubMed]

131. Sarraf, S.A.; Raman, M.; Guarani-Pereira, V.; Sowa, M.E.; Huttlin, E.L.; Gygi, S.P.; Harper, J.W. Landscape of the PARKINdependent ubiquitylome in response to mitochondrial depolarization. Nature 2013, 496, 372-376. [CrossRef] [PubMed]

132. Livnat-Levanon, N.; Glickman, M.H. Ubiquitin-proteasome system and mitochondria-reciprocity. Biochim. Biophys. Acta 2011, 1809, 80-87. [CrossRef] [PubMed]

133. Lehmann, G.; Udasin, R.G.; Ciechanover, A. On the linkage between the ubiquitin-proteasome system and the mitochondria. Biochem. Biophys. Res. Commun. 2016, 473, 80-86. [CrossRef] [PubMed]

134. Azzu, V.; Brand, M.D. Degradation of an intramitochondrial protein by the cytosolic proteasome. J. Cell Sci. 2010, 123, 578-585. [CrossRef]

135. Chan, N.C.; Salazar, A.M.; Pham, A.H.; Sweredoski, M.J.; Kolawa, N.J.; Graham, R.L.; Hess, S.; Chan, D.C. Broad activation of the ubiquitin-proteasome system by Parkin is critical for mitophagy. Hum. Mol. Genet. 2011, 20, 1726-1737. [CrossRef]

136. Yoshii, S.R.; Kishi, C.; Ishihara, N.; Mizushima, N. Parkin mediates proteasome-dependent protein degradation and rupture of the outer mitochondrial membrane. J. Biol. Chem. 2011, 286, 19630-19640. [CrossRef]

137. Wiertz, E.J.; Tortorella, D.; Bogyo, M.; Yu, J.; Mothes, W.; Jones, T.R.; Rapoport, T.A.; Ploegh, H.L. Sec61-mediated transfer of a membrane protein from the endoplasmic reticulum to the proteasome for destruction. Nature 1996, 384, 432-438. [CrossRef]

138. Ng, W.; Sergeyenko, T.; Zeng, N.; Brown, J.D.; Römisch, K. Characterization of the proteasome interaction with the Sec61 channel in the endoplasmic reticulum. J. Cell Sci. 2007, 120, 682-691. [CrossRef]

139. Wu, X.; Rapoport, T.A. Mechanistic insights into ER-associated protein degradation. Curr. Opin. Cell Biol. 2018, 53, 22-28. [CrossRef]

140. Pickles, S.; Vigié, P.; Youle, R.J. Mitophagy and quality control mechanisms in mitochondrial maintenance. Curr. Biol. 2018, 28, r170-r185. [CrossRef]

141. Sun, Z.; Brodsky, J.L. Protein quality control in the secretory pathway. J. Cell Biol. 2019, 218, 3171-3187. [CrossRef] [PubMed]

142. Montenegro-Venegas, C.; Fienko, S.; Anni, D.; Pina-Fernández, E.; Frischknecht, R.; Fejtova, A. Bassoon inhibits proteasome activity via interaction with PSMB4. Cell Mol. Life Sci. 2021, 78, 1545-1563. [CrossRef] [PubMed]

143. Bingol, B.; Schuman, E.M. Activity-dependent dynamics and sequestration of proteasomes in dendritic spines. Nature 2006, 441, 1144-1148. [CrossRef] [PubMed]

144. Bingol, B.; Sheng, M. Deconstruction for reconstruction: The role of proteolysis in neural plasticity and disease. Neuron 2011, 69 , 22-32. [CrossRef]

145. Bingol, B.; Wang, C.-F.; Arnott, D.; Cheng, D.; Peng, J.; Sheng, M. Autophosphorylated CaMKII $\alpha$ acts as a scaffold to recruit proteasomes to dendritic spines. Cell 2010, 140, 567-578. [CrossRef]

146. Ehlers, M.D. Activity level controls postsynaptic composition and signaling via the ubiquitin-proteasome system. Nat. Neurosci. 2003, 6, 231-242. [CrossRef] 
147. Otero, M.G.; Alloatti, M.; Cromberg, L.E.; Almenar-Queralt, A.; Encalada, S.E.; Pozo Devoto, V.M.; Bruno, L.; Goldstein, L.S.; Falzone, T.L. Fast axonal transport of the proteasome complex depends on membrane interaction and molecular motor function. J. Cell Sci. 2014, 127, 1537-1549. [CrossRef]

148. Liu, K.; Jones, S.; Minis, A.; Rodriguez, J.; Molina, H.; Steller, H. PI31 Is an adaptor protein for proteasome transport in axons and required for synaptic development. Dev. Cell 2019, 50, 509-524.e10. [CrossRef]

149. Shi, L.; Liu, B.; Shen, D.-D.; Yan, P.; Zhang, Y.; Tian, Y.; Hou, L.; Jiang, G.; Zhu, Y.; Liang, Y.; et al. A tumor-suppressive circular RNA mediates uncanonical integrin degradation by the proteasome in liver cancer. Sci. Adv. 2021, 7, eabe5043. [CrossRef]

150. Ramachandran, K.V.; Fu, J.M.; Schaffer, T.B.; Na, C.H.; Delannoy, M.; Margolis, S.S. Activity-dependent degradation of the nascentome by the neuronal membrane proteasome. Mol. Cell 2018, 71, 169-177.e6. [CrossRef]

151. Ramachandran, K.V.; Margolis, S.S. A mammalian nervous-system-specific plasma membrane proteasome complex that modulates neuronal function. Nat. Struct. Mol. Biol. 2017, 24, 419-430. [CrossRef] [PubMed]

152. Türker, F.; Cook, E.K.; Margolis, S.S. The proteasome and its role in the nervous system. Cell Chem. Biol. 2021, 28, 903-917. [CrossRef] [PubMed]

153. Sahu, I.; Mali, S.M.; Sulkshane, P.; Xu, C.; Rozenberg, A.; Morag, R.; Sahoo, M.P.; Singh, S.K.; Ding, Z.; Wang, Y.; et al. The 20S as a stand-alone proteasome in cells can degrade the ubiquitin tag. Nat. Commun. 2021, 12, 6173. [CrossRef] [PubMed]

154. Shibahara, T.; Kawasaki, H.; Hirano, H. Identification of the $19 S$ regulatory particle subunits from the rice $26 \mathrm{~S}$ proteasome. Eur. J. Biochem. 2002, 269, 1474-1483. [CrossRef] [PubMed]

155. Kikuchi, J.; Iwafune, Y.; Akiyama, T.; Okayama, A.; Nakamura, H.; Arakawa, N.; Kimura, Y.; Hirano, H. Co- and post-translational modifications of the $26 \mathrm{~S}$ proteasome in yeast. Proteomics 2010, 10, 2769-2779. [CrossRef] [PubMed]

156. Kimura, A.; Kato, Y.; Hirano, H. N-myristoylation of the Rpt2 subunit regulates intracellular localization of the yeast $26 \mathrm{~S}$ proteasome. Biochemistry 2012, 51, 8856-8866. [CrossRef]

157. Kimura, A.; Kurata, Y.; Nakabayashi, J.; Kagawa, H.; Hirano, H. N-Myristoylation of the Rpt2 subunit of the yeast $26 \mathrm{~S}$ proteasome is implicated in the subcellular compartment-specific protein quality control system. J. Proteom. 2016, 130, 33-41. [CrossRef] [PubMed]

158. Kimura, Y.; Saeki, Y.; Yokosawa, H.; Polevoda, B.; Sherman, F.; Hirano, H. N-Terminal modifications of the 195 regulatory particle subunits of the yeast proteasome. Arch. Biochem. Biophys. 2003, 409, 341-348. [CrossRef]

159. Zong, C.; Gomes, A.V.; Drews, O.; Li, X.; Young, G.W.; Berhane, B.; Qiao, X.; French, S.W.; Bardag-Gorce, F.; Ping, P. Regulation of murine cardiac $20 S$ proteasomes: Role of associating partners. Circ. Res. 2006, 99, 372-380. [CrossRef]

160. Wang, X.; Chen, C.F.; Baker, P.R.; Chen, P.L.; Kaiser, P.; Huang, L. Mass spectrometric characterization of the affinity-purified human 26S proteasome complex. Biochemistry 2007, 46, 3553-3565. [CrossRef]

161. Thinon, E.; Serwa, R.A.; Broncel, M.; Brannigan, J.A.; Brassat, U.; Wright, M.H.; Heal, W.P.; Wilkinson, A.J.; Mann, D.J.; Tate, E.W. Global profiling of co- and post-translationally N-myristoylated proteomes in human cells. Nat. Commun. 2014, 5, 4919. [CrossRef] [PubMed]

162. Farazi, T.A.; Waksman, G.; Gordon, J.I. The biology and enzymology of protein N-myristoylation. J. Biol. Chem. 2001, 276, 39501-39504. [CrossRef] [PubMed]

163. Johnson, D.R.; Bhatnagar, R.S.; Knoll, L.J.; Gordon, J.I. Genetic and biochemical studies of protein N-myristoylation. Annu. Rev. Biochem. 1994, 63, 869-914. [CrossRef] [PubMed]

164. Rajala, R.V.; Datla, R.S.; Moyana, T.N.; Kakkar, R.; Carlsen, S.A.; Sharma, R.K. N-myristoyltransferase. Mol. Cell Biochem. 2000, 204, 135-155. [PubMed]

165. Kamps, M.P.; Buss, J.E.; Sefton, B.M. Mutation of NH2-terminal glycine of p60src prevents both myristoylation and morphological transformation. Proc. Natl. Acad. Sci. USA 1985, 82, 4625-4628. [CrossRef] [PubMed]

166. Lam, S.S.; Martell, J.D.; Kamer, K.J.; Deerinck, T.J.; Ellisman, M.H.; Mootha, V.K.; Ting, A.Y. Directed evolution of APEX2 for electron microscopy and proximity labeling. Nat. Methods 2015, 12, 51-54. [CrossRef]

167. Marmor-Kollet, H.; Siany, A.; Kedersha, N.; Knafo, N.; Rivkin, N.; Danino, Y.M.; Moens, T.G.; Olender, T.; Sheban, D.; Cohen, N.; et al. Spatiotemporal proteomic analysis of stress granule disassembly using APEX reveals regulation by SUMOylation and links to ALS pathogenesis. Mol. Cell 2020, 80, 876-891.e6. [CrossRef]

168. Liu, Q.; Zheng, J.; Sun, W.; Huo, Y.; Zhang, L.; Hao, P.; Wang, H.; Zhuang, M. A proximity-tagging system to identify membrane protein-protein interactions. Nat. Methods 2018, 15, 715-722. [CrossRef]

169. Zavodszky, E.; Peak-Chew, S.Y.; Juszkiewicz, S.; Narvaez, A.J.; Hegde, R.S. Identification of a quality-control factor that monitors failures during proteasome assembly. Science 2021, 373, 998-1004. [CrossRef]

170. Wang, X.; Cimermancic, P.; Yu, C.; Schweitzer, A.; Chopra, N.; Engel, J.L.; Greenberg, C.; Huszagh, A.S.; Beck, F.; Sakata, E.; et al. Molecular details underlying dynamic structures and regulation of the human 26S proteasome. Mol. Cell Proteom. 2017, 16, 840-854. [CrossRef]

171. Tomko, R.J., Jr.; Hochstrasser, M. The intrinsically disordered Sem1 protein functions as a molecular tether during proteasome lid biogenesis. Mol. Cell 2014, 53, 433-443. [CrossRef] [PubMed]

172. Katayama, H.; Kogure, T.; Mizushima, N.; Yoshimori, T.; Miyawaki, A. A sensitive and quantitative technique for detecting autophagic events based on lysosomal delivery. Chem. Biol. 2011, 18, 1042-1052. [CrossRef] [PubMed]

173. Martinez-Fonts, K.; Davis, C.; Tomita, T.; Elsasser, S.; Nager, A.R.; Shi, Y.; Finley, D.; Matouschek, A. The proteasome $19 S$ cap and its ubiquitin receptors provide a versatile recognition platform for substrates. Nat. Commun. 2020, 11, 477. [CrossRef] [PubMed] 
174. Tomita, T.; Hirayama, S.; Sakurai, Y.; Ohte, Y.; Yoshihara, H.; Saeki, Y.; Hamazaki, J.; Murata, S. Specific modification of aged proteasomes revealed by tag-exchangeable knock-in mice. Mol. Cell Biol. 2019, 39, e00426-18. [CrossRef] [PubMed]

175. Jongkamonwiwat, N.; Ramirez, M.A.; Edassery, S.; Wong, A.C.Y.; Yu, J.; Abbott, T.; Pak, K.; Ryan, A.F.; Savas, J.N. Noise exposures causing hearing loss generate proteotoxic stress and activate the proteostasis network. Cell Rep. 2020, 33, 108431. [CrossRef]

176. Xie, F.; Su, P.; Pan, T.; Zhou, X.; Li, H.; Huang, H.; Wang, A.; Wang, F.; Huang, J.; Yan, H.; et al. Engineering extracellular vesicles enriched with palmitoylated ACE2 as COVID-19 therapy. Adv. Mater. 2021, 49, e2103471. [CrossRef]

177. Huang, R.; Han, M.; Meng, L.; Chen, X. Transcriptome-wide discovery of coding and noncoding RNA-binding proteins. Proc. Natl. Acad. Sci. USA 2018, 115, e3879-e3887. [CrossRef]

178. Castello, A.; Fischer, B.; Eichelbaum, K.; Horos, R.; Beckmann, B.M.; Strein, C.; Davey, N.E.; Humphreys, D.T.; Preiss, T.; Steinmetz, L.M.; et al. Insights into RNA biology from an atlas of mammalian mRNA-binding proteins. Cell 2012, 149, 1393-1406. [CrossRef]

179. Quinodoz, S.A.; Jachowicz, J.W.; Bhat, P.; Ollikainen, N.; Banerjee, A.K.; Goronzy, I.N.; Blanco, M.R.; Chovanec, P.; Chow, A.; Markaki, Y.; et al. RNA promotes the formation of spatial compartments in the nucleus. Cell 2021, 184, 5775-5790.e30. [CrossRef] [PubMed]

180. Brehm, A.; Liu, Y.; Sheikh, A.; Marrero, B.; Omoyinmi, E.; Zhou, Q.; Montealegre, G.; Biancotto, A.; Reinhardt, A.; Almeida de Jesus, A.; et al. Additive loss-of-function proteasome subunit mutations in CANDLE/PRAAS patients promote type I IFN production. J. Clin. Investig. 2015, 125, 4196-4211. [CrossRef]

181. Torrelo, A. CANDLE syndrome as a paradigm of proteasome-related autoinflammation. Front. Immunol. 2017, 8, 927. [CrossRef] [PubMed] 